\title{
Phenology, Yield and Yield Components of Maize as Affected by Humic Acid and Nitrogen
}

\author{
Kamran Azeem ${ }^{1}$, Shad Khan Khali1 ${ }^{1}$, Farmanullah Khan ${ }^{2}$, Shahenshah ${ }^{1}$, Abdul Qahar ${ }^{1}$, Muhammad Sharif ${ }^{2}$ \& \\ Muhammad Zamin ${ }^{3}$ \\ ${ }^{1}$ Department of Agronomy, The University of Agriculture Peshawar, Pakistan \\ ${ }^{2}$ Department of soil and environmental science, The University of Agriculture Peshawar, Pakistan \\ ${ }^{3}$ Department of Horticulture, The University of Agriculture Peshawar, Pakistan \\ Correspondence: Kamran Azeem, Department of Agronomy, The University of Agriculture Peshawar, Pakistan. \\ Tel: 92-333-896-7446. E-mail: azeemmkd@gmail.com
}

Received: April 18, 2014 Accepted: May 4, 2014 Online Published: June 15, 2014

doi:10.5539/jas.v6n7p286 URL: http://dx.doi.org/10.5539/jas.v6n7p286

\begin{abstract}
In this research we studied the role of humic acid and nitrogen in improving the phenology, growth and productivity of maize (Zea mays L.). Field experiment was carried out at the New Developmental Farm of the University of Agriculture Peshawar during Autumn 2011. Zea mays L. cultivar, Azam was sown. Two factors were studied using three levels of humic acid $\left(1.5,3\right.$ and $\left.4.5 \mathrm{~kg} \mathrm{ha}^{-1}\right)$ and four levels of nitrogen $(80,120,160$ and $\left.200 \mathrm{~kg} \mathrm{ha}^{-1}\right)$. Humic acid was applied at sowing time whereas $1 / 3^{\text {rd }}$ nitrogen at sowing time, and $1 / 3^{\text {rd }}$ at $4-5$ leaf stage and remaining $1 / 3^{\text {rd }}$ at tasseling stage in comparison with control. The experiment was laid out in randomized complete block design having four replications. Non-significant parameter was emergence $\mathrm{m}^{-2}$ while significant were days to silking, thousand grain weight, grain yield and grain per ear. Days to silking was delayed with increase in levels of humic acid and nitrogen. Humic acid levels significantly increased grains ear ${ }^{-1}$ and grain yield ha $^{-1}$ with $3 \mathrm{~kg} \mathrm{HA} \mathrm{ha}^{-1}$ while no effect was observed in thousand grains weight. Nitrogen increased grains ear ${ }^{1}$, thousand grains weight $(\mathrm{g})$ and grains yield ha ${ }^{-1}$ at the rate of $160 \mathrm{~kg} \mathrm{~N} \mathrm{ha}^{-1}$ as compared to other levels and control. Hence it is concluded that $3 \mathrm{~kg} \mathrm{HA} \mathrm{ha}^{-1}$ and $160 \mathrm{~kg} \mathrm{~N}^{-1}$ gave significant results.
\end{abstract}

Keyswords: maize, humic acid, nitrogen, phenology and yield

\section{Introduction}

Maize (Zea mays L.) ranks $3^{\text {rd }}$ in world's cereals crops after wheat and rice as food crop (Chaudary, 1994). It is the $2^{\text {nd }}$ most staple crop after wheat in the Khyber Pakhtunkhwea (KP) (Amanullah et al., 2009). Maize is used as a food for human diet, feed poultry and animals. It is used as raw materials for preparation of starch, corn, dextrose, corn syrup and corn flakes industries (Khaliq et al., 2004). Humic acid (HA) is added as fertilizer at the rate of 1 or $2 \mathrm{~kg} \mathrm{ha}^{-1}$ which supplement soil with nitrogen from $0.04-0.08 \mathrm{~kg} \mathrm{ha}^{-1}$ and phosphorous from $0.001 \mathrm{~kg} \mathrm{ha}^{-1}$, which can not meet crop requirements for nutrition.(Sharif et al., 2002). Tomato growth was affected by the HA used in the form of organic waste (Atiyeh et al., 2002). It decomposes organic matter that can affect plant growth and development by fixed nutrients available to the crops (Tahir et al., 2010). It significantly enhanced phosphorus (P) and NO3-N of the calcium-containing soil and has good effect on availability of potassium (Tahir et al., 2011). Due to its organic nature when applied as foliar spray it produces maximum dry matter as compared with control and nitrogen (Delfine, 2005). The use of organic matter increases soil fertility and productivity. Humic acid is one of the important source of organic matter in soil (Chen \& Aviad, 1990). Humic acid application to the soil is strongly associated with the physical, chemical and biological properties of the soil (Khattak \& Muhammad, 2008). Application of humic acid increased soil acidity, soil organic carbon and cation exchange capacity (Hanafi \& Salwa, 1998). Wheat growth and nitrogen uptake is increased with increasing level of humic acid (Tahir et al., 2011). Potassium humate a product of HA increases the release of primary macronutrients ( N, P and K). Nitrogen is released significantly up to $20 \mathrm{~kg}$ humic acid ha ${ }^{-1}$, while phosphorus and potassium up to $40 \mathrm{~kg}$ humic acid ha $\mathrm{g}^{-1}$. The release of nitrogen and phosphorus took longer period of 60 days while potassium was released for relatively shorter period of 45 days after incubation. Organic carbon and cation exchange capacity were significantly increased at the end of incubation period (Sathiya et al., 2003). Nitrogen is the key element in increasing grain yield and quality of maize. Nitrogen contributes $1-4 \%$ of dry matter production of the plants (Haque et al., 2001). 
In recent years emphasis has been given to increase fertilizers use efficiency by top dressing and split applications of nitrogenous fertilizers at critical growth stages of maize (Singh, 1985). Nitrogen deficiency causes stunted growth, delayed maturity and pale green or yellow color (chlorosis) of the leaves (Haque et al., 2001). Habtegebrial et al. (2007) suggested that addition of $\mathrm{N}$ and appropriate nitrogen level affect yield and yield components of maize considerably. Nitrogen sources and nitrogen levels significantly affect the agronomic performance of maize. Application of $\mathrm{N}$ increases soil fertility and crop productivity. About $43-68 \%$ increase in yield and $25-42 \%$ increase in biomass were-observed with the addition of nitrogen fertilizer (Ogola et al., 2002). When nitrogen is deficient in the soil, then addition of $\mathrm{N}$ fertilizer from outer source increased the grain yield of maize (Wienhold et al., 1995). The present research was therefore designed to evaluated he effect of $\mathrm{N}$ levels and $\mathrm{HA}$ on phenology and yield of maize.

\section{Materials and Methods}

\subsection{Site Description}

This study was carried out during summer (Kharif) season of 2011. The site is located at the the new developmental farm of the University of Agriculture Peshawar, which is located at latitude of $34^{0} \mathrm{~N}$ and longitude of $72^{\circ} \mathrm{E}$. The farm soil is clay loamy having $\mathrm{pH}$ values ranges between 6-7. This region is cold, having the winter rainfall (smaller in quantity of 30-40\% of the total rainfall throughout the year) due to the cold air currents from Mediterranean and Gulf disturbances.

\subsection{Experimental Description}

An experiment was conducted at New Developmental Farm, The University of Agriculture Peshawar Pakistan; to study the "effect of different levels of humic acid and nitrogen on phenology and yield of maize" during 2011. The experiment was carried out in 2-factorial randomized complete block design having four replications. A plot size of $15 \mathrm{~m}^{2}$ having 4 rows $5 \mathrm{~m}$ long was used. Distance from plant to plant was $25 \mathrm{~cm}$ while row to row distance was kept as $75 \mathrm{~cm}$. All the agronomic practices were applied when needed. A based dose of $90 \mathrm{~kg}$ phosphorus ha ${ }^{-1} \mathrm{was}^{\mathrm{s}}$ applied at time of sowing. Azam variety was sown on $30^{\text {th }}$ June 2011 and maintained recommend population of 60000 plant ha $^{-1}$. Three levels of humic acid $\left(1.5,3\right.$ and $\left.4.5 \mathrm{~kg} \mathrm{ha}^{-1}\right)$ were applied at sowing whereas four nitrogen levels $\left(80,120,160\right.$ and $\left.200 \mathrm{~kg} \mathrm{ha}^{-1}\right)$ were applied $1 / 3^{\text {rd }}$ at sowing, $1 / 3^{\text {rd }}$ at $4-5$ leaf stage and remaining $1 / 3^{\text {rd }}$ at tasseling stage in comparison to control.

\subsection{Data Analysis}

The data were statistically analyzed using factorial RCB design and means were compared using LSD test at 0.05 level of probability (Jan et al., 2009).

\section{Results and Discussion}

\subsection{Emergences $m^{-2}$}

Statistical analysis of data revealed that emergence $\mathrm{m}^{-2}$ was not significantly affected by all factorsas presented in Table 1. It might be due to the fact that humic acid and fertilizer response is not so quick to be observed immediately after two weeks. Moreover seedling emergence is mostly related to the reserved food present in seed. Similar results were reported by Zhenqing et al. (1995) and Kolsarici et al. (2005) who reported that humic acid had no effect on germination of wheat seeds and sunflower, respectively. These results agreed to as reported by Walter et al. (1995) and Moselhy and Zahran (2002) who reported that emergence $\mathrm{m}^{-2}$ was not significantly affected by nitrogen. Hadi et al. (2012) who reported that seed use its own endosperm for germination and plants did not utilize nutrients from external source. Fertilizer application had no effects on emergence $\mathrm{m}^{-2}$ (Shah et al., 2009).

\subsection{Days to Silking}

Meditation of the data revealed that days to silking were significantly affected by humic acid, nitrogen levels and control vs. rest comparison (Table 2). The interaction between humic acid and nitrogen levels was significant. Delayed silking (56.2) was observed with application $4.5 \mathrm{~kg} \mathrm{HA} \mathrm{ha}^{-1}$ while early silking (55.1 and 55.0 days) were observed with application 1.5 and $3 \mathrm{~kg} \mathrm{HA} \mathrm{ha}{ }^{-1}$ which is statistically at far with each other. Similarly days to silking (56.2, 55.5 and 55.3 days) were taken with application of 200,160 and $120 \mathrm{~kg} \mathrm{~N}^{-1}$, respectively which were statically at par while early silking (54.8 days was recorded at $80 \mathrm{~kg} \mathrm{~N} \mathrm{ha}^{-1}$. The gap showed that silking delayed linearly with application of $4.5 \mathrm{~kg} \mathrm{HA} \mathrm{ha}^{-1}$ with increasing of nitrogen levels from 80 to $200 \mathrm{~kg} \mathrm{ha}^{-1}$. Similarly application $1.5 \mathrm{~kg} \mathrm{HA} \mathrm{ha}^{-1}$ has linearly increased days to silking with increase in level of $\mathrm{N}$ from 80 to $120 \mathrm{~kg}$ then a slight decrease with increasing level of $\mathrm{N}$ up to $160 \mathrm{~kg} \mathrm{ha}^{-1}$ then continuous increase with increasing level of $\mathrm{N}$ up to $200 \mathrm{~kg} \mathrm{~N} \mathrm{ha}^{-1}$ (Figure 1). Rest treated plots took more days to silking (55.5 days) than control (53.0 
days) plots. The delay in silking might be due to nutrients availability in sufficient quantity which ultimately increased growing period of crop and these results were agreed to Lie et al. (2003). Similarly delay in days to silking in maize was observed with increase in $\mathrm{N}$ rate which might be due to that nitrogen increase vegetative growth vigorously. The results agreed with Amanullah et al. (2009) who stated that increase in level of N application delays silking in maize). Zeidan and Amany (2006) reported that nitrogen fertilizer boost up vegetative growth and enhancing seed yield. Arif et al. (2010) reported that nitrogen play an important role in vegetative growth and development. Nitrogen significantly delayed tasseling, silking and maturity in maize.

Table 1. Emergence $\mathrm{m}^{-2}$, days to silking, grains ear ${ }^{-1}$, thousand grains weight $(\mathrm{g})$ and grain yield $\left(\mathrm{kg} \mathrm{ha}^{-1}\right)$ as affected by humic acid and nitrogen levels

\begin{tabular}{lccccc}
\hline Humic Acid $\left(\mathrm{kg} \mathrm{ha}^{-1}\right)$ & Emergences $\mathrm{m}^{-2}$ & Days to silking & Grain ear $^{-1}$ & Thousand grains weight $(\mathrm{g})$ & Grain yield $\left(\mathrm{kg} \mathrm{ha}^{-1}\right)$ \\
\hline 1.5 & 24 & $55 \mathrm{~b}$ & $400 \mathrm{~b}$ & 225 & $3190 \mathrm{~b}$ \\
3 & 27 & $55 \mathrm{~b}$ & $432 \mathrm{a}$ & 233 & $3602 \mathrm{a}$ \\
4.5 & 27 & $57 \mathrm{a}$ & $415 \mathrm{ab}$ & 223 & $3598 \mathrm{a}$ \\
LSD & $\mathrm{ns}$ & 0.49 & 14 & $\mathrm{~ns}$ & 188 \\
Nitrogen $\left(\mathrm{kg} \mathrm{ha}^{-1}\right)$ & & & & & \\
80 & 27 & $55 \mathrm{~b}$ & $398 \mathrm{~b}$ & $217 \mathrm{~b}$ & $3183 \mathrm{~b}$ \\
120 & 26 & $55 \mathrm{ab}$ & $413 \mathrm{ab}$ & $229 \mathrm{ab}$ & $3381 \mathrm{~b}$ \\
160 & 26 & $56 \mathrm{ab}$ & $432 \mathrm{a}$ & $239 \mathrm{a}$ & $3957 \mathrm{a}$ \\
200 & 26 & $57 \mathrm{a}$ & $421 \mathrm{~b}$ & $223 \mathrm{~b}$ & $3332 \mathrm{~b}$ \\
LSD & $\mathrm{ns}$ & 0.57 & 17 & 10 & 217 \\
Control vs rest & & & & & $2650 \mathrm{~b}$ \\
Control & 26 & $53 \mathrm{~b}$ & $301 \mathrm{~b}$ & $198 \mathrm{~b}$ & $3463 \mathrm{a}$ \\
Rest & 26 & $56 \mathrm{a}$ & $416 \mathrm{a}$ & $227 \mathrm{a}$ & 153 \\
LSD & $\mathrm{ns}$ & 0.40 & 12 & 7.3 & $* *$ \\
Interaction & & & & $* *$ & \\
HA x N & ns & $* *$ & $* *$ & & $* 3$ \\
\hline
\end{tabular}

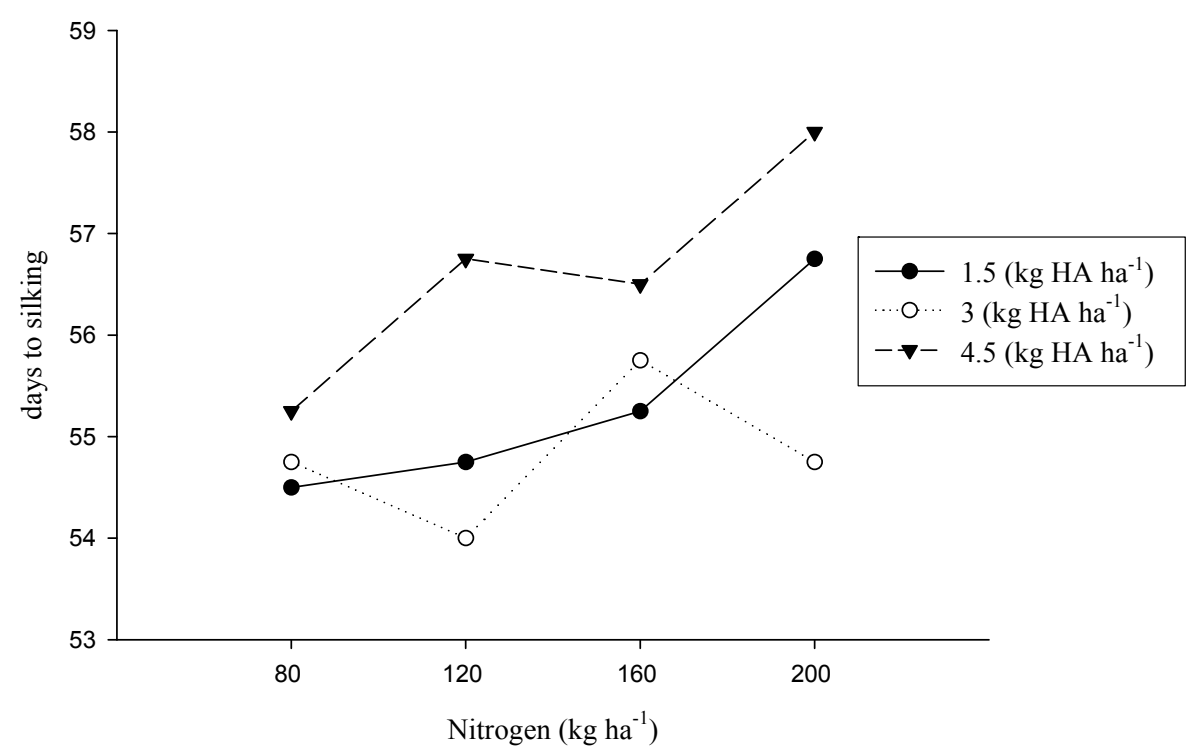

Figure 1. Days to silking as affected by humic acid and nitrogen interaction 
Table 2. Analysis of variance emergence $\mathrm{m}^{-2}$, days to silking, grains ear ${ }^{-1}$, thousand grains weight $(\mathrm{g})$ and grain yield $\left(\mathrm{kg} \mathrm{ha}^{-1}\right)$ as affected by humic acid and nitrogen levels

\begin{tabular}{lcccccc}
\hline S.O.V & DF & Emergences $\mathrm{m}^{-2}$ & Days to silking & Grain ear $^{-1}$ & Thousand grains weight $(\mathrm{g})$ Grain yield $\left(\mathrm{kg} \mathrm{ha}^{-1}\right)$ \\
\hline Replication & 3 & $19.1 \mathrm{~ns}$ & $3.23 \mathrm{~ns}$ & $2298 \mathrm{~ns}$ & $503 \mathrm{~ns}$ & $191746 \mathrm{~ns}$ \\
Treatments & {$[12]$} & $25.0 \mathrm{~ns}$ & $7.19^{*}$ & $6649^{*}$ & $1028^{*}$ & $866134^{*}$ \\
Control vs Rest & 1 & $1.54 \mathrm{~ns}$ & $24.64^{*}$ & $48955^{*}$ & $3222^{*}$ & $2442503^{*}$ \\
Humic acid (HA) & 2 & $42.6 \mathrm{~ns}$ & $14.02^{*}$ & $4147^{*}$ & $405 \mathrm{~ns}$ & $896603^{*}$ \\
Nitrogen (N) & 3 & $4.85 \mathrm{~ns}$ & $6.56^{*}$ & $2430^{*}$ & $1014^{*}$ & $1385196^{*}$ \\
HA x N & 6 & $33.1 \mathrm{~ns}$ & $2.33^{*}$ & $2542^{*}$ & $878^{*}$ & $333719^{*}$ \\
Error & 36 & 14.4 & 0.95 & 806 & 311 & 137041 \\
\hline Total & 51 & & & &
\end{tabular}

\subsection{Grain ear ${ }^{-1}$}

Analysis of the data indicated that grains ear $^{-1}$ was significantly affected by humic acid, nitrogen levels and control vs. rest comparison and also by the interaction between humic acid and nitrogen (Table 2). Maximum number of grains ear ${ }^{-1}$ (432.2) was recorded with application of $3 \mathrm{~kg} \mathrm{HA} \mathrm{ha}^{-1}$ while lower number of grains (400) was observed with application $1.5 \mathrm{~kg} \mathrm{HA} \mathrm{ha}^{-1}$. Similarly higher number of grains ear ${ }^{-1}$ (431, 420 and 413) was noted when applying 160, 200 and $120 \mathrm{~kg} \mathrm{~N} \mathrm{ha}^{-1}$ respectively, which are statically similar with each other while lower number of grains ear ${ }^{-1}$ (397) was observed with nitrogen at the rate of $80 \mathrm{~kg} \mathrm{ha}^{-1}$. Graph showed that application of $1.5 \mathrm{~kg} \mathrm{HA} \mathrm{ha}^{-1}$ and $\mathrm{N}$ from 80 to $160 \mathrm{~kg}$ has increased grain ear ${ }^{-1}$. like wise application of $3 \mathrm{~kg} \mathrm{HA} \mathrm{ha}^{-1} \mathrm{has}$ increased grains per ear with $\mathrm{N}$ levels from 80 to $200 \mathrm{~kg} \mathrm{~N} \mathrm{ha}^{-1}$ and similarly $4.5 \mathrm{~kg} \mathrm{HA} \mathrm{ha}^{-1}$ first decreased grains per ear with nitrogen level from 80 to $120 \mathrm{~kg} \mathrm{~N} \mathrm{ha}^{-1}$. Also the data revealed that increase in $\mathrm{N}$ has increased grains ear $^{-1}$ up to $160 \mathrm{~kg} \mathrm{~N} \mathrm{ha}^{-1}$ and further increase in $\mathrm{N}$ has reduced grains ear ${ }^{-1}$ (Figure 2). Control vs rest plots produced more grains ear $^{-1}$ (415) than control (300) plots. This increase in grains ear ${ }^{-1}$ might be due to the

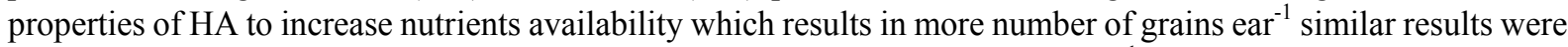
reported by Sarir et al. (2005) who reported maximum number of grains ear ${ }^{-1}$ in maize and wheat with the application of HA to the soil. Similarly, Akhtar (2001) found that grains were significantly increased by increasing levels of N. Arif et al. (2010) reported that yield and yield components was significant higher with application of nitrogenous fertilizer. Optimum utilization of solar light, higher assimilates production and its conversion to starches resulted higher grains number and weight that resulted more biomass and seed yield (Derby et al., 2004). Yield and yield components was significantly increased by nitrogen levels (El-sheikh, 1998; Samira et al., 1998).

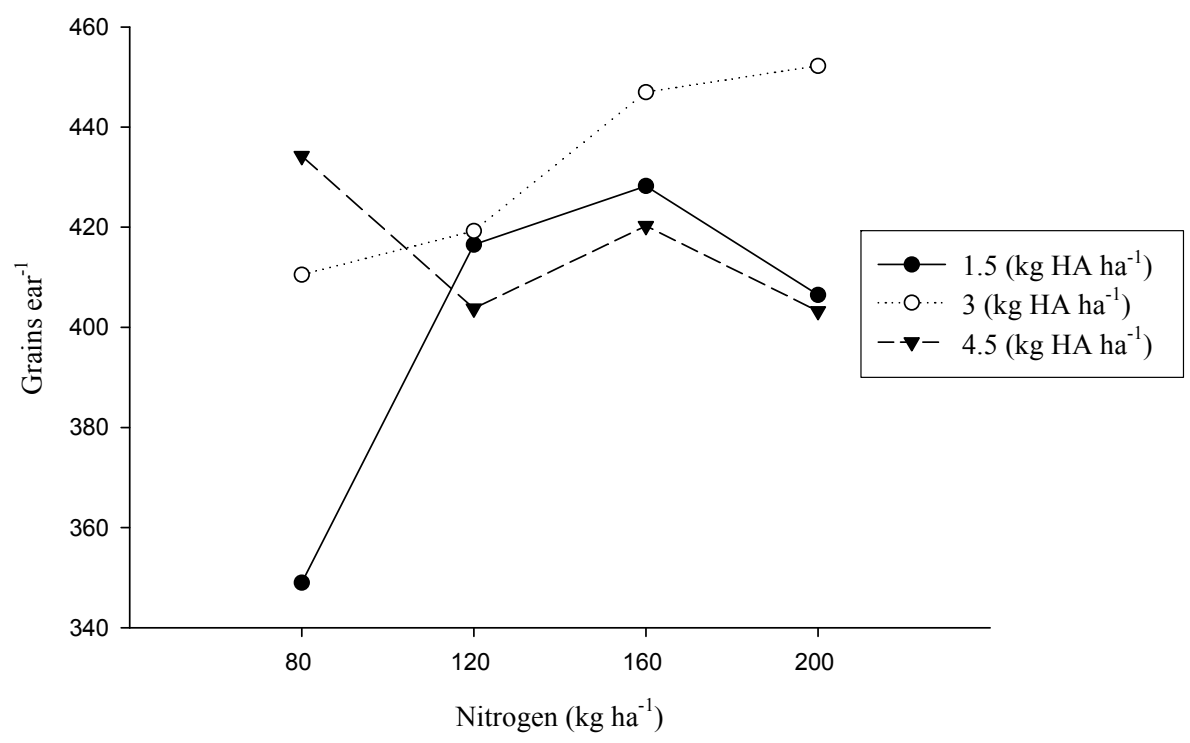

Figure 2. Grains ear ${ }^{-1}$ as affected by humic acid and nitrogen interaction 


\subsection{Thousand Grains Weight (g)}

Thousand grains weight $(\mathrm{g})$ was significantly affected by nitrogen levels and control vs. rest comparison while humic acid levels had no affect on thousand grains weight (Table 2). The interaction between humic acid and nitrogen levels was significantly affected. Maximum thousand grains weight (239 and $229 \mathrm{~g}$ ) was recorded with application of 160 and $120 \mathrm{~kg} \mathrm{~N} \mathrm{ha}^{-1}$ respectively which are statically similar with each other while lighter thousand grains weight (217 and $223 \mathrm{~g}$ ) was noted with applying 80 and $200 \mathrm{~kg} \mathrm{~N} \mathrm{ha}^{-1}$ respectively. Graph trend shoed that application of $1.5 \mathrm{~kg} \mathrm{HA} \mathrm{ha}^{-1}$ first decline with application of $\mathrm{N}$ from 80 to $120 \mathrm{~kg} \mathrm{~N} \mathrm{ha}^{-1}$ then further increased in $\mathrm{N}$ thousand grain weight increase upto $160 \mathrm{~kg}$ for further increase of upto $200 \mathrm{~kg} \mathrm{~N}^{-1}$ thousand grains weight decreased. Similarly $3 \mathrm{~kg} \mathrm{HA} \mathrm{ha}^{-1}$ showed that thousand grain weight increased with increasing of $\mathrm{N}$ from 80 to $120 \mathrm{~kg} \mathrm{~N} \mathrm{ha}^{-1}$ for further increase of $\mathrm{N}$ thousand grains weight decreased. Similarly $4.5 \mathrm{~kg} \mathrm{HA} \mathrm{ha}{ }^{-1}$ showed that thousand grains weight increased linearly with increasing of $\mathrm{N}$ from 80 to $160 \mathrm{~kg}$ for further increase of $\mathrm{N}$ thousand grain weight decreased (Figure 3). Rest treated plots produces more thousand grains weight (227 g) than control (197 g) plots. Humic acid had no significant on thousand grins weight and the results are similar with those of Malik and Akber (2008). Maximum thousand grain weight might be due to the fact nitrogen enhances yield and yield components. These results are in conformity to those of Alam et al. (2003). They reported that maximum thousand grain weight was recorded with plots receiving $120 \mathrm{~kg} \mathrm{~N} \mathrm{ha}^{-1}$. Optimum utilization of solar light, higher assimilates production and its conversion to starches resulted higher grains number and weight that resulted more biomass and seed yield (Derby et al., 2004). Yield and yield components was significantly increased by nitrogen levels (El-sheikh, 1998; Samira et al., 1998). Arif et al. (2010) reported that thousand grains weight significantly increased with application of $160 \mathrm{~kg} \mathrm{~N} \mathrm{ha}^{-1}$. Optimum utilization of solar light, higher assimilates production and its conversion to starches resulted higher grains number and weight that resulted more biomass and seed yield (Derby et al., 2004).

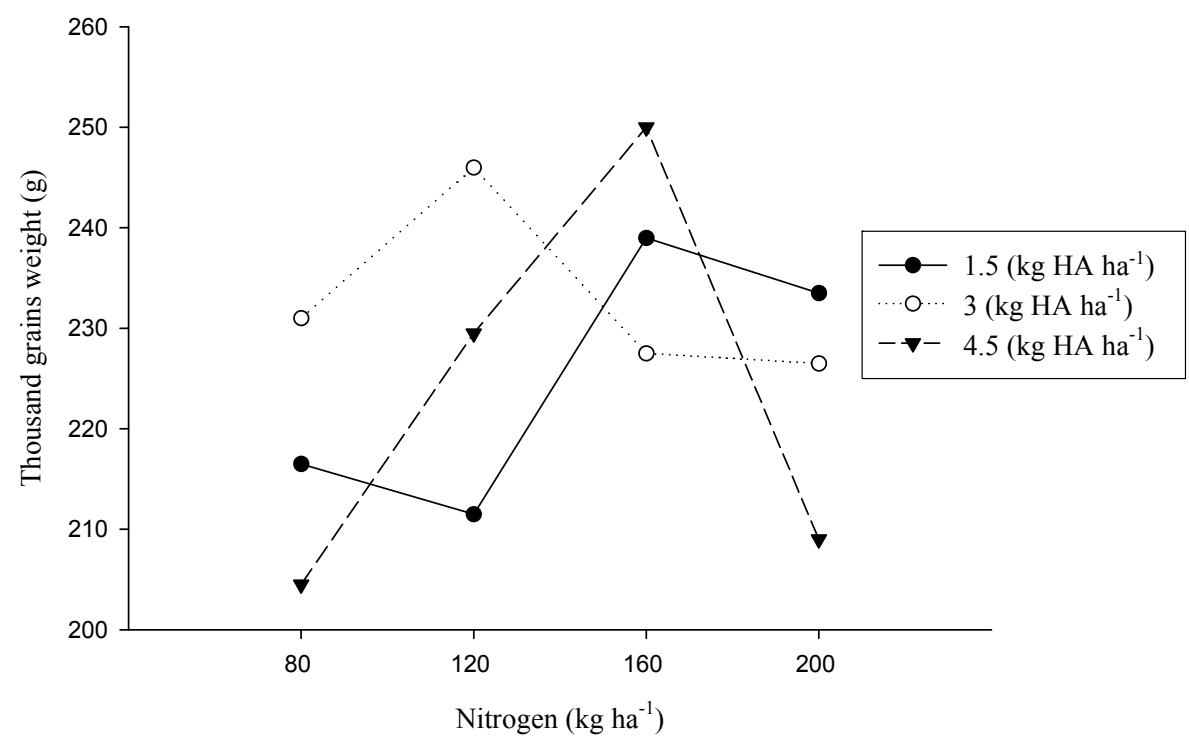

Figure 3. Thousand grains weight as affected by humic acid and nitrogen interaction

\subsection{Grain Yield $\left(\mathrm{kg} \mathrm{ha}^{-1}\right)$}

Humic acid, nitrogen and control vs. rest comparison had significantly affected grain yield $\mathrm{kg} \mathrm{ha}^{-1}$ However, the interaction response of humic acid and nitrogen levels was also significant (Table 2). Higher grain yield (3602 and $3597 \mathrm{~kg} \mathrm{ha}^{-1}$ ) was recorded when applying 3 and $4.5 \mathrm{~kg} \mathrm{HA} \mathrm{ha}^{-1}$ which is statistically similar with each other while minimum grain yield $\left(3190 \mathrm{~kg} \mathrm{ha}^{-1}\right)$ were recorded with $1.5 \mathrm{~kg} \mathrm{HA} \mathrm{ha}^{-1}$. Similarly maximum grain yield $(3957 \mathrm{~kg}$ $\mathrm{ha}^{-1}$ ) were noted with application $160 \mathrm{~kg} \mathrm{~N} \mathrm{ha}^{-1}$ while lower grain yield $\left(3380,3332\right.$ and $\left.3183 \mathrm{~kg} \mathrm{ha}^{-1}\right)$ was observed when applying 120, 200 and $80 \mathrm{~kg} \mathrm{~N}^{-1}$ respectively. The graph showed that a steep increase was observed in grain yield when applying humic acid at the rate of 1.5 and $4.5 \mathrm{~kg} \mathrm{ha}^{-1}$ with nitrogen levels of 80 to 160 $\mathrm{kg} \mathrm{ha}^{-1}$ where as application of $3 \mathrm{~kg} \mathrm{HA} \mathrm{ha}{ }^{-1}$ decreased grain yield with nitrogen level of 80 to $120 \mathrm{~kg} \mathrm{~N}^{-1}$ as shown in Figure 4. Control vs Rest plots produced higher grain yield (3463 $\left.\mathrm{kg} \mathrm{ha}^{-1}\right)$ than control $\left(2650 \mathrm{~kg} \mathrm{ha}^{-1}\right)$ 
plots. The ability of HA to release the nutrient slowly due to the decomposition of residue for a longer time could be the possible explanation for improved grain yield due HA application (Dev \& Bhardwaj, 1995) and sharif et al. (2003)who reported that humic acid alone can increase the grain yield by $21-25 \%$ with nutrients accumulation . These results are in agreement with Ortiz Monasterio et al. (1997) who reported that N application increased biomass and grain yield of the crop. Optimum utilization of solar light, higher assimilates production and its conversion to starches resulted higher grains number and weight that resulted more biomass and seed yield (Derby et al., 2004). Yield and yield components was significantly increased by nitrogen levels (El-sheikh, 1998; Samira et al., 1998). Zeidan and Amany (2006) reported that nitrogen fertilizer boost up vegetative growth and enhancing seed yield. Sheikh (1998) reported that grain yield of maize increased with $160 \mathrm{~kg} \mathrm{~N} \mathrm{ha}^{-1}$.

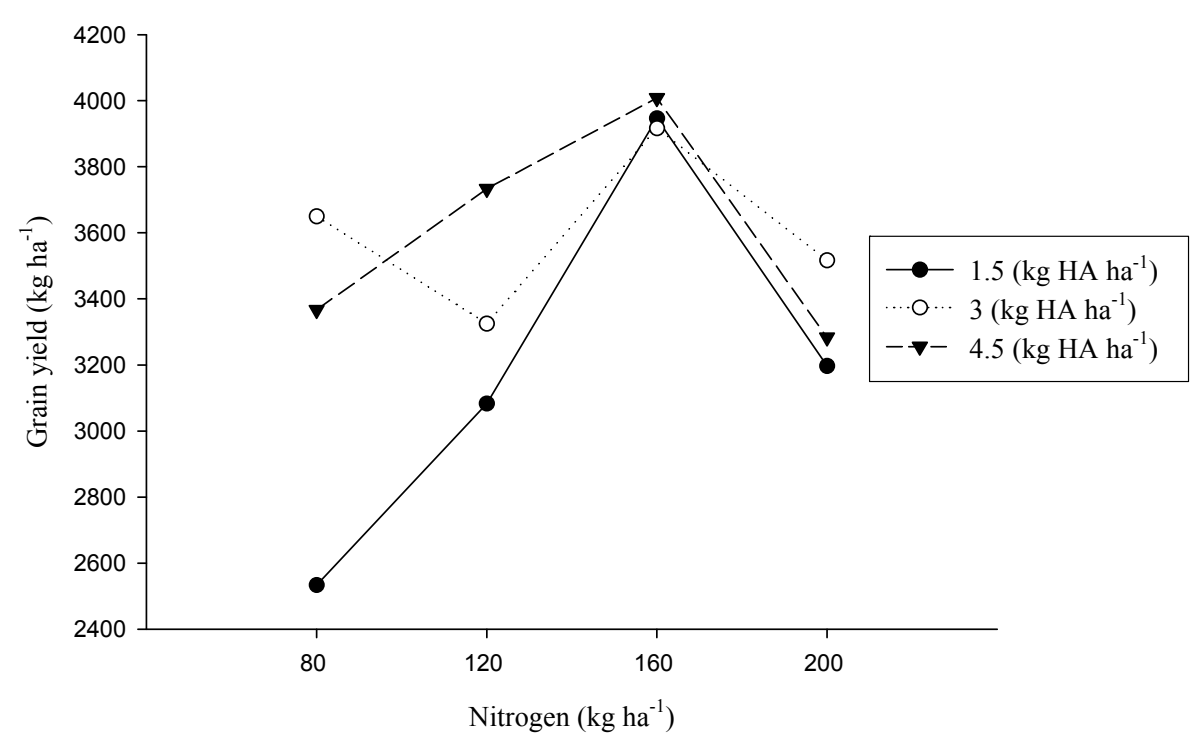

Figure 4. Grain yield $\left(\mathrm{kg} \mathrm{ha}^{-1}\right)$ as affected by humic acid and nitrogen interaction

\section{Conclusion}

From the results and discussion mentioned it is concluded that the yield and yield components of Zea mays L. were maximum when applying $3 \mathrm{~kg} \mathrm{HA} \mathrm{ha}^{-1}$ and $160 \mathrm{~kg} \mathrm{~N} \mathrm{ha}^{-1}$. Hence $3 \mathrm{~kg} \mathrm{HA} \mathrm{ha}^{-1}$ and $160 \mathrm{~kg} \mathrm{~N} \mathrm{ha}^{-1}$ is recommended for higher grain yield and $4.5 \mathrm{~kg} \mathrm{HA} \mathrm{ha}^{-1}$ and $200 \mathrm{~kg} \mathrm{~N} \mathrm{ha}^{-1}$ for higher crop growth.

\section{Acknowledgments}

The authors are indebted to the University of Agriculture Peshawar, Pakistan for providing technical and financial support for this research.

\section{References}

Akhtar, M. M. (2001). Effect of varying levels of nitrogen on growth and yield performance of two new wheat cultivars (pp. 84-86). M.Sc (Hons) thesis, Deparment of Agronomy, Uni. of Agri. Faisalabad.

Amanullah, Asif, M., Malhi, S. S., \& Khattak, R. A. (2009a). Effects of phosphorus fertilizer source and plant density on growth and yield of maize in northwestern Pakistan. Journal of Plant Nutrition, 32(12), 2080-2093. http://dx.doi.org/10.1080/01904160903308168

Amanullah, R. A., Khattak, S. K., \& Khattak, R. A. (2009b). Effects of plant density and N on phenology and yield of maize. Journal of Plant Nutrition, 32(3), 245-259.

Arif, M., Amin, I., Jan, M. T., Munir, I. Q. B. A. L., Nawab, K. H. A. L. I. D., Khan, N. U., \& Marwat, K. B. (2010). Effect of plant population and nitrogen levels and methods of application on ear characters and yield of maize. Pak. J. Bot, 42(3), 1959-1967.

Atiyeh, R. M., Lee, S., Edwards, C. A., Arancon, N. Q., \& Metzger, J. D. (2002). The influence of humic acids on growth and yield of durum wheat. Agronomy for sustainable Development, 25(2), 183-191.

Chaudhry, F. M. (1994). Kharif cereal crops. In E. Bashir \& R. Bantel (Eds), Crop production. NBF, Islamabad. 
Chen, Y., \& Aviad, T. (1990). Effect of Humic Substances on Plant Growth. In Humic Substances in Soil.

Delfine, S., Tognetti, R., Desiderio, E., \& Alvino, A. (2005). Effect of foliar application of N and HA on growth and yield of durum wheat. Agron. Sust. Dev., 25(2), 183-191. http://dx.doi.org/10.1051/agro:2005017

Derby, N. E., Casey, F. X. M., Knighton, R. E., \& Steel, D. D. (2004). Midseason nitrogen fertility management for corn based on weather and yield prediction. Agron. J., 96, 494-501. http://dx.doi.org/10.2134/ agronj2004.0494

Dev, S. P., \& Bhardwaj, K. K. K. (1995). Effect of crop wastes and nitrogen levels of biomass production and nitrogen uptake in wheat-maize sequence. An. Agric. Res., 16, 264-267.

El-Sheikh, F. T. (1998). Effect of soil application of nitrogen and foliar application with manganese on grain yield and quality of maize (Zea mays L). Proc. 8th Conf. Agron., Suez Canal Univ., Ismailia, Egypt, 28-29 Nov., pp. 182-189.

Hafidi, M., Amir, S., Meddich, A., Jouraiphy, A., Winterton, P., El Gharous, M., \& Duponnois, R. (2012). Impact of applying composted biosolids on wheat growth and yield parameters on a calcimagnesic soil in a semi-arid region. African Journal of Biotechnology, 11(41), 9805-9815.

Hanafi, M. M., \& Salwa, H. (1998). Influence of HA addition on soil properties and their adsorption. Commun. Soil Sci. Plant Anal., 29, 1933-1947. http://dx.doi.org/10.1080/00103629809370083

Haque, M. M., Hamid, A., \& Bhuiyan, N. I. (2001). Nutrient uptake and productivity as affected by nitrogen and potassium application levels in maize/sweet potato intercropping system". Korean J. Crop Sci., 46(1), 1-5.

Jan, M. T., Shah, P., Hoolinton, P. A., Khan, M. J., \& Sohail, Q. (2009). Agriculture Research: Design and Analysis. Deptt. of Agronomy, KPK Agric. Uni. Peshawar, Pakistan.

Khaliq, T. A. S. N. E. E. M., Mahmood, T. A. R. I. Q., Kamal, J. A. V. E. D., \& Masood, A. M. I. R. (2004). Effectiveness of farmyard manure, poultry manure and nitrogen for corn (Zea mays L.) productivity. Int. $J$. Agric. Biol, 2, 260-263.

Khan, K., Iqbal, M., Shah, Z., Ahmad, B., Azim, A., \& Sher, H. (2003). Grain and stover yield of corn with varying times of plant density reduction. Pak. J. Biol. Sci, 6(19), 1641-1643. http://dx.doi.org/10.3923/pjbs.2003.1641.1643

Khattak, M. K., Khan, M. J., Mughal, A. Q., Bukhari, S. B., \& Jan, M. T. (2004). Influence of various tillage practices on yield of wheat-maize under clay loam soil condition. Sarhad. J. Agric, 20, 429-435.

Kolsarici, O., Kaya, M. D., \& Day, S. (2005). Effects of humic acid rate on emergence and seedling growth of sunflower. Ziraat Fakültesi Dergisi, 18(2), 151-155.

Li, H., Han, Y., \& Cai, Z. (2003). Nitrogen mineralization in paddy soils of the Taihu region of China under anaerobic conditions: dynamics and model fitting. Geoderma, 115, 161-175. http://dx.doi.org/10.1016/S0016-7061(02)00358-0

Mosely, E. I., \& Zahran, M. A. (2002). Effect of bio and mineral nitrogen fertilization on barley crop grown on a sandy soil. Egypt. J. Agric. Res., 3, 921-936.

Ortiz-Monasterio, J. I., Sayre, K. D., Rajaram, S., \& McMahom, M. (1997). Genetic progress in wheat yield and nitrogen use efficiency under four nitrogen rates. Crop Sci., 37, 898-904. http://dx.doi.org/10.2135/ cropsci1997.0011183X003700030033x

Samira M., Hussein, A., Haikel, M. A., \& El-Masry, M. A. (1998). Effect of some preceding crops, hill spacing and nitrogen fertilization on yield attributes and grain yield of maize under reclaimed sandy soil conditions in East Delta. Proc. 8th Conf. Agron. (pp. 174-181). Suez Canal Univ., Ismailia, Egypt, 28-29 Nov.

Sarir, M. S., Sharif., M., Zeb, A., \& Akhlaq, M. (2005). Influence of different levels of humic acid application by various methods on the yield and yield components of maize. Sarhad. J. Agric., 21(1), 75-81.

Sathiya, B. K., Selvakumari, G., Santhi, R., \& Singaram, P. (2003). Effect of humic acid on nutrient release pattern in an Alfisol (Typic).

Shah, S. T. H., Shahid-Ibni-Zamir, M., Waseem, M., Ali, A., Tahir, M., \& Waleed, B. K. (2009). Growth and yield response of maize to organic and inorganic sources of nitrogen. Pak. J. life. Soc. Sci., 7(2), 108-111.

Shang, Z. Q., Han, J. M., Li, G. M., \& Wang, X. F. (1995). Study on the synergistic action of humic acid on absorption and transportation of phosphate in wheat by using the 32P tracer method. J. Hebei Agric. Univ., 18(3), 10-15. 
Sharif, M., Khattak, R. A., \& Sarrir, M. S. (2002). Effect of different levels of lignitic coal derived HA on growth of maize plants. Commun. in Soil Sci. and Plants Anal (pp. 19-20).

Singh, R. P. (1985). Prospects and problems of $N$ and $P$ top dressing in wheat. Paper presented at 24th workshop. All India Wheat Research Workers, held at G.B. Pantnagar Univ. Agril. Tech.

Tahir, M. M., Khurshid, M., Khan, M. Z., Abbasi, M. K., \& Kazmi, M. H. (2011). Lignite-derived humic acid effect on growth of wheat plants in different soils. Pedosphere, 21(1), 124-131. http://dx.doi.org/ 10.1016/S1002-0160(10)60087-2

Walter, E. B., Christianson, C. B., \& Lamothe, A. G. (1995). The effect of nitrogen fertilizer on growth, grain yield and yield component of malting barley. Field Crop Res., 43, 87-99. http://dx.doi.org/ 10.1016/0378-4290(95)00034-N

Wienhold, B. J., Trooien, T. P., \& Reichman, G. A. (1995). Yield and nitrogen use efficiency of irrigated corn in the northern Great Plains. Agron. J., 87, 842-846. http://dx.doi.org/10.2134/agronj1995.000219620087000 $50010 \mathrm{x}$

Zeidan, M. S., Amany, M. F., \& El-Kramany, B. (2006). Effect of N-Fertilizer and Plant Density on Yield and Quality of Maize in Sandy Soil. Res. J. Agric. Biol. Sci., 2(4), 156-161.

\section{Copyrights}

Copyright for this article is retained by the author(s), with first publication rights granted to the journal.

This is an open-access article distributed under the terms and conditions of the Creative Commons Attribution license (http://creativecommons.org/licenses/by/3.0/). 